\title{
The role of lamivudine versus entecavir in prevention of HCC in patients with hepatitis $B$ virus-related cirrhosis
}

\author{
Cristina Olariu ${ }^{1,2^{*}}$, Adriana Nurciu $^{3}$, Oana Șchiopu ${ }^{1,2}$, Magdalena Popa $^{4}$, Dan Olteanu ${ }^{3}$ \\ From The 9th Edition of the Scientific Days of the National Institute for Infectious Diseases Prof Dr Matei Bals \\ Bucharest, Romania. 23-25 October 2013
}

\section{Background}

In Romania, the incidence of hepatocellular carcinoma (HCC) has increased over the past ten years due to the increasing number of cirrhotic patients (more than 90\% of the cases of HCC develop in cirrhosis). Antiviral nucleos $(t)$ ide analogues have been widely used to reduce the development of HCC in chronic hepatitis B patients with fibrosis or cirrhosis.

\section{Methods}

We included 36 patients with hepatitis B virus related cirrhosis. Since February 2008 until now, 45\% (16 patients) were treated with lamivudine and 55\% (20 patients) with entecavir. The evaluation was performed every 3-4 months by clinical exam, biochemical and serological tests, and abdominal ultrasonography for all patients. Upper endoscopy, computed tomography scanning or magnetic resonance imaging were done in selective cases.

\section{Results}

The median age at the diagnosis of cirrhosis was $57.6 \pm 10.7$ years and $75 \%$ of patients were males. Six cases $(16.66 \%)$ were diagnosed with HCC - all of them were males. Only one of these patients was treated with entecavir, while the rest received lamivudine. Risk factors involved in carcinogenesis were represented by: age over 60 , male gender, cirrhosis evolution for more than 5 years.

\footnotetext{
* Correspondence: ol_cristina@yahoo.ro

'National Institute for Infectious Diseases "Prof. Dr. Matei Balş", Bucharest, Romania
}

Full list of author information is available at the end of the article

\section{Conclusion}

The results of this study suggested that the incidence of HCC is lower in patients with HBV-related cirrhosis who used entecavir (5\%) compared to lamivudine (31\%).

\section{Authors' details \\ 'National Institute for Infectious Diseases "Prof. Dr. Matei Balş", Bucharest, Romania. ${ }^{2}$ Carol Davila University of Medicine and Pharmacy, Bucharest, Romania. ${ }^{3}$ University Emergency Hospital, Bucharest, Romania. ${ }^{4}$ Elias University Emergency Hospital, Bucharest, Romania.}

Published: 16 December 2013

doi:10.1186/1471-2334-13-S1-P69

Cite this article as: Olariu et al:: The role of lamivudine versus entecavir in prevention of $\mathrm{HCC}$ in patients with hepatitis B virus-related cirrhosis. BMC Infectious Diseases 2013 13(Suppl 1):P69.
Submit your next manuscript to BioMed Central and take full advantage of:

- Convenient online submission

- Thorough peer review

- No space constraints or color figure charges

- Immediate publication on acceptance

- Inclusion in PubMed, CAS, Scopus and Google Scholar

- Research which is freely available for redistribution

Submit your manuscript at www.biomedcentral.com/submit
C Biomed Central
C Biomed Central

(C) 2013 Olariu et al; licensee BioMed Central Ltd. This is an Open Access article distributed under the terms of the Creative Commons Attribution License (http://creativecommons.org/licenses/by/2.0), which permits unrestricted use, distribution, and reproduction in any medium, provided the original work is properly cited. 